\title{
A shortened version of the Mitchell method for determination of the biological value of protein. Growth rate as a source of error
}

\author{
By L. R. NJAA \\ Governmental Vitamin Laboratory, Norwegian Fisheries Research Institute, \\ Bergen, Norway \\ (Received I4 Fuly r958-Revised 12 Fanuary 1959)
}

The biological value of protein as determined by the Mitchell method (Mitchell, 1923-4a; Mitchell \& Carman, 1926), at a constant dietary level of protein, is influenced by age (Henry \& Kon, 1957) and body-weight (Bell \& Loosli, 195I) of the experimental animals. For the same protein source the biological value may vary from one experiment to another (Henry \& Kon, 1956) and also between periods within one experiment (Bartlett, Henry, Kon, Osborne, Thompson \& Tinsley, I938). If the dietary level of protein was varied, the biological value decreased with increasing protein content (Mitchell, 1923-4b). Despite these shortcomings of the method, the biological value of a protein source is often considered one of its characteristics.

A shortened version of the Mitchell method was worked out and compared with the original. It was hoped that the influence of time factors would be reduced when the new version was used. This hope was substantiated in experiments with two herring meals as test proteins. It was found that the growth rate of the rats accounted for a great part of the variation in the biological value observed for each herring meal. This effect was mainly due to a close relationship between the growth rate and the urinary excretion of nitrogen. The food intake and the protein content were kept constant in these experiments. The influence of these variables is discussed by Njaa (1959).

EXPERIMENTAL

Biological values of dietary protein were determined by two methods.

$$
\text { Method of Mitchell (Mitchell, I923-4a, Mitchell } \& \text { Carman, 1926) (A) }
$$

Six pairs of litter-mate rats of our own breeding were used in four feeding periods, each of Io days. Within pairs the rats were of the same sex. Faeces and urine were collected for the last 6 days of each period; carmine was used as a faeces marker. In the first and fourth periods a low egg-protein diet was given to all rats. Values obtained in these periods were used for calculation of metabolic and endogenous nitrogen losses (Mitchell \& Carman, 1926). In the second period one rat of each pair was given one of the two herring-meal diets and its litter-mate the other; in the third period the diets were reversed. The rats weighed $60-75 \mathrm{~g}$ at the beginning and $125-\mathrm{r} 35 \mathrm{~g}$ at the end of the experiment. 


\section{Shortened version of the Mitchell method $(B)$}

Eight triads of litter-mate rats weighing from 70 to $80 \mathrm{~g}$ were used. Within triads the rats were of the same sex. One rat in each was given the low egg-protein diet and each of the other two a different herring-meal diet. The experiment was first done with four triads (period $\mathrm{I}$ ) and then repeated with four new triads (period 2). Each period lasted Io days, and faeces and urine were collected as described above.

Table I. Percentage composition of experimental diets

\begin{tabular}{|c|c|c|c|}
\hline \multirow[b]{2}{*}{ Constituent } & \multirow{2}{*}{$\begin{array}{c}\text { Egg-protein } \\
\text { diet }\end{array}$} & \multicolumn{2}{|c|}{ Herring-meal diet } \\
\hline & & $I$ & 2 \\
\hline Egg powder, acetone-dried & $5 \cdot 90$ & $\ldots$ & -. \\
\hline Herring meal no. I & $\longrightarrow$ & 13.50 & 一 \\
\hline Herring meal no. 2 & - & - & 13.64 \\
\hline Potato starch, partly dextrinized & $65 \cdot 10$ & $57 \cdot 5^{\circ}$ & $57 \cdot 36$ \\
\hline Sucrose & $20 \cdot 00$ & $20 \cdot 00$ & $20 \cdot 00$ \\
\hline Arachis oil & $5 \cdot 00$ & $5^{\cdot 00}$ & $5 \cdot 00$ \\
\hline Salts (Sure, I94I) & $4 \cdot 00$ & $4 \cdot 00$ & 4.00 \\
\hline
\end{tabular}

Vitamins of the B complex were mixed into the diet daily. Each rat was given $\mathrm{I} \cdot 25 \mathrm{ml}$ of a solution containing $25 \mu \mathrm{g}$ each of thiamine, riboflavin, pyridoxine and nicotinic acid, ${ }_{5 \circ}^{\circ} \mu \mathrm{g}$ calcium pantothenate, $\mathrm{I} \mathrm{mg}$ inositol, $3 \mathrm{mg}$-aminobenzoic acid and $9 \mathrm{mg}$ choline chloride. Vitamins $\mathrm{A}$ and $\mathrm{D}$ were given by dropper once weekly, about rooo i.u. vitamin $\mathrm{A}$ and roo i.u. vitamin $\mathrm{D} / \mathrm{rat}$.

\section{Procedure}

The percentage composition of the experimental diets is given in Table $\mathrm{r}$. Herring meals nos. I and 2 contained $74^{\circ} \mathrm{I}$ and $73.3 \%$ conventional protein $(\mathrm{N} \times 6.25)$, respectively. The protein level in the herring-meal diets was $10 \%$ and in the eggprotein diet $4.5 \%$. Tests with the two methods were done at about the same time in the same rack within twenty-four metabolism cages. All rats were offered Io $g$ food daily. The daily ration for each was taken from a jar weighed before and after the collection period. During this period the jar was kept in the animal room. Spilling was reduced by mixing the daily ration with water. The food offered was eaten completely. In both methods the metabolic faecal nitrogen and the endogenous urinary nitrogen were calculated on the basis of food consumption and mean bodyweight, respectively. In method $A$ the ratios between the faecal nitrogen and the food intake and between the urinary nitrogen and the mean body-weight were assumed to vary linearly from period i to period 4 . In method $B$ these ratios were determined for one rat in each triad and the metabolic and the endogenous nitrogen for the two other rats were calculated on this basis. Faeces and urine were collected daily and kept in normal sulphuric acid. The faeces from each rat were digested in bulk; portions of the urine were taken for digestion. Copper sulphate was used as a catalyst. Nitrogen was determined by the method of Ma \& Zuazaga (1942). The $t$ test was used to test the differences between methods within meals and the mean differences between meals within periods for significance. The effects of meals and periods in method $A$ and the effect of period in method $B$ were tested for significance by analysis of variance. The directly obtained values in method $A$ and the differences between meals in method $B$ were analysed. Total, partial and multiple correlation coefficients were calculated and tested for significance according to the methods given by Snedecor (1946). 


\section{RESULTS}

The biological values obtained for the herring meals in the two periods with each method as well as the grand averages for each method are given in Table 2. Urinary excretions of nitrogen, mean body-weights and mean daily weight gains of the experimental rats are also given. With both methods significantly different biological values for the two herring meals were found $(P<0.05$ for both methods). The difference between meals was not significantly greater in method $A$ than in method $B$. When comparison between methods was based upon grand averages for each herring meal, differences were not significant. Analysis of variance indicated that the difference between periods was significant in method $A(P<0.01)$ but not in method $B$. When differences between urinary nitrogen excretions were studied instead of differences between biological values, substantially the same results were obtained.

In Table 3 are given the results from an analysis of covariance with the biological value (B.v.) as the dependent variable, and the mean body-weight $(W)$ and the daily weight gain $(\Delta W)$ as independent variables. There were highly significant partial correlations between B.v. and $\Delta W$. The partial correlation between B.v. and $W$ was not significant for herring meal no. $\mathrm{I}$, and on the borderline of significance $(P \sim 0.05)$ for herring meal no. 2. When the urinary nitrogen excretion was considered as the dependent variable instead of the biological value corresponding results were obtained (Table 3).

\section{DISCUSSION}

The shortened version of the Mitchell method compared favourably with the original. With both, the relative ranking of the herring meals was the same in each experimental period. With the original version the biological values for both herring meals were significantly higher in the first than in the second experimental period. No such difference was observed with the shortened version. Analysis of covariance on the combined values for each herring meal with the biological value as the dependent, and the mean body-weight and the daily weight gain as the independent variables indicated that the growth rate was the more important factor of the two having influence upon the biological value (Table 3 ). The growth rates of the experimental rats were more uniform with the shortened version than with the original. Thus the better agreement for the biological values determined in the two periods of the former may be explained. By definition the biological value is a measure of protein utilization for maintenance and growth. It is obvious, therefore, that the biological value is influenced by differences in growth rate. The positive correlation between protein efficiency ratios and biological values for different protein sources demonstrated by Block \& Mitchell (1946-7) and by Bender (1956) is a consequence of this. The interdependence of biological value and growth rate with the same protein source has received little attention. This source of 'error' may, however, be a common explanation for variation in biological value ascribed to age (Henry \& Kon, 1957) and body-weight (Bell \& Loosli, I95I) of experimental animals, and to different batches of rats of about the same age and weight (Henry \& Kon, 1956). The last authors suggested that a standard protein should be examined together with the proteins to be tested, and that comparisons should be 





made with reference to the standard protein. This procedure has much to recommend it. It implies, however, that the biological values determined possess a relative rather than an absolute significance (Mitchell, Burroughs \& Beadles, 1936). My results indicated that the relative ranking of the two herring meals was rather constant despite great variation in the absolute values (Table 2).

In many experiments on the biological value of proteins reported in the literature, the food intakes as well as the mean body-weights and the growth rates of experimental animals varied. Indications as to the relative importance of these variables upon variations observed in the biological values were sought by subjecting three sets of literature data to analysis of covariance. These referred to two diets (III and IV) tested by Macrae, Henry \& Kon ( 1943 ) and to the diet tested by Mayfield \& Hedrick (1949). In the latter, variations in the intake of the B vitamins were left out of consideration. Total and partial correlation coefficients between the biological value and the growth rate were positive and either significant or on the borderline of significance. Correlation coefficients between the biological value and either the mean body-weight or the food intake were not significant. Multiple correlation coefficients were all significant. The observation made in experiments on herring meals (Table 3) that variation in the growth rate was a major source of 'error' in determination of the biological value, was thus confirmed by the literature data considered.

Endogenous and metabolic losses of nitrogen were estimated in different ways in the two versions of the Mitchell method tested. Because of the high degree of correlation for combined values between the biological value and the growth rate (Table 3) it is tentatively concluded that this difference has introduced little 'error' in the determination of the biological value. The procedure used in the shortened version is similar to that used by Miller \& Bender (1955). Columbus (1954) and Nehring \& Haesler (1954) also estimated endogenous and metabolic nitrogen on animals other than those on the test diets. Estimation of endogenous urinary and metabolic faecal nitrogen and its influence upon experimental error will be discussed in later communications.

In the present experiments the growth rate could be singled out as an important factor having influence upon error in determinations of biological value. Analysis of the primary data revealed that this infuence could be wholly explained by a close interdependence between the urinary excretion of nitrogen and the growth rate (Table 3).

\section{SUMMARY}

I. The biological value of herring-meal protein was determined in experiments with young rats.

2. A shortened version of the Mitchell method for determination of the biological value of protein was worked out.

3. The shortened version was compared with the original in experiments with two herring meals. The two versions gave substantially the same results. The relative ranking of two herring meals was the same with both versions.

4. It was demonstrated by analysis of covariance that variations in the growth rate were an important source of 'error' in the determination of the biological value. 


\title{
REFERENCES
}

Bartlett, S., Henry, K. M., Kon, S. K., Osborne, L. W., Thompson, S. Y. \& Tinsley, J. (1938). Biochem. F. 32, 2024.

Bell, J. M. \& Loosli, J. K. (195 r). F. Anim. Sci. xo, 50.

Bender, A. E. (1956). Brit. F. Nutr. 10, 135.

Block, R. J. \& Mitchell, H. H. (1946-7). Nutr. Abstr. Rev. r6, 249.

Columbus, A. (1954). Arch. Tierernähr. Beihefte, no. 4, p. 5 I.

Henry, K. M. \& Kon, S. K. (1956). Brit. F. Nutr. 1o, 39.

Henry, K. M. \& Kon, S. K. (1957). Brit. F. Nutr. I1, 305.

Ma, T. S. \& Zuazaga, G. (1 942). Industr. Engng Chem. (Anal.), 14, 280.

Macrae, T. F., Henry, K. M. \& Kon, S. K. (1943). Biochem. F. 37, 225.

Mayfield, H. L. \& Hedrick, M. T. (1949). F. Nutr. 37, 475.

Miller, D. S. \& Bender, A. E. (1955). Brit. F. Nutr. 9, $3^{82 .}$

Mitchell, H. H. (1923-4a). F. biol. Chem. 58, 873 .

Mitchell, H. H. (1923-4b). F. biol. Chem. 58, 905.

Mitchell, H. H., Burroughs, W. \& Beadles, J. R. (1936). F. Nutr. Ir, 257.

Mitchell, H. H. \& Carman, G. G. (1926). F. biol. Chem. 68, i83.

Nehring, K. \& Haesler, E. (1954). Arch. Tierernähr. Beihefte, no. 5, p. I 10.

Njaa, L. R. (1959). Brit. F. Nutr. 13, 142.

Snedecor, G. W. (1946). Statistical Methods Applied to Experiments in Agriculture and Biology, 4th ed. Ames, Iowa: The Iowa State College Press.

Sure, B. (1941). F. Nutr. 22, 499.

\section{Biological value of herring-meal protein. Urinary nitrogen excretion in relation to protein content of diet and food intake}

\author{
By L. R. NJAA \\ Governmental Vitamin Laboratory, Norwegian Fisheries Research Institute, \\ Bergen, Norway \\ (Received $\mathrm{I}_{4}$ Fuly $\mathrm{1} 95^{8}-$ Revised $\mathrm{I} 2$ Fanuary 1959)
}

In a previous communication ( $\mathrm{Njaa}$, I959) a close relationship between the growth rate of experimental rats and the biological value of herring-meal protein determined on them was demonstrated. Analysis of covariance indicated that under the conditions used the body-weight was of minor importance. The food intake and the protein concentration of the diets were kept constant. Increased protein content of the diet has been reported to decrease the biological value, but variations in the intake of food of a constant protein content were without effect (Mitchell, 1923-4). Though the former observation has been confirmed by many (Chick, Boas-Fixsen, Hutchinson \& Jackson, I935; Columbus, I954; Nehring \& Haesler, 1954; Henry \& Kon, 1957; Forbes, Vaughan \& Yohe, I958), confirmation of the latter does not seem to have been published. The observations of Bender (1956) that net protein utilization for rollerdried skim milk and for bread fortified with lysine did not vary with the food intake have no direct bearing on this point since the different food intakes were not compared in the same experiment. 